\title{
RANCANGAN SISTEM PERSEDIAAN BAHAN BAKU MENGGUNAKAN MODEL PERSEDIAAN STOCHASTIC JOINT REPLENISHMENT
}

\author{
Oleh : \\ Edi Susanto \\ Jurusan Teknik Industri, Institut Teknologi Nasional Bandung \\ Email: edsusanto@itenas.ac.id \\ Mutiara Cahaya Putri \\ Jurusan Teknik Industri, Institut Teknologi Nasional Bandung \\ Emsosfi Zaini \\ Jurusan Teknik Industri, Institut Teknologi Nasional Bandung \\ Dedeng Abdul Gani Amruloh \\ Program Studi Manajemen - STIE DR KHEZ Muttaqien \\ Email : dedeng.amrullah@gmail.com
}

\section{Article Info}

Article History:

Received 30 July - 2020

Accepted 20 August - 2020

Available Online

07 Sept -2020

\begin{abstract}
Control of raw material inventory is necessary for companies to ensure the smooth running of the production process. PT. SEA is a company engaged in making Al-Quran. The supply system carried out by the company still uses intuition, by placing separate orders for each type of raw material if the raw material inventory in the warehouse is deficient. Orders for raw materials are made without considering other raw materials from the same supplier. Which resulted in high inventory costs. The right solution to this problem is to use the stochastic inventory model in the joint replenishment case. This method produces a combined order time interval and maximum inventory for each type of raw material. The frequency of orders made by the company based on past data is made 13 times to 5 times per year. This resulted in a savings in the frequency of ordering time of 61.58\%. time. Meanwhile, savings in supply costs from the start is IDR 989,840,767.50 per year per year. The total cost of supplies using the design results was valued at Rp. 982,254,563.75 per year, saving about $R p .7,586.20375$ per year or down about $0.7 \%$.
\end{abstract}

\section{Keyword :}

Stochastic, Joint

Replenishment, Inventory

Control

\section{PENDAHULUAN}

Persaingan di dunia industri saat ini semakin berkembang, hal ini didasari dengan banyaknya perusahaan yang bergerak di bidang industri manufaktur. Semakin banyak perusahaan yang bergerak di bidang industri manufaktur, maka mengharuskan perusahaan untuk memiliki ide yang kreatif untuk bersaing dengan perusahaan-perusahaan lainnya.

PT. SEA merupakan salah satu perusahaan yang bergerak dibidang industri manufaktur. Produk yang dihasilkan oleh PT. SEA adalah Al-Quran. Bahan baku yang digunakan dalam pembuatan Al-Quran terdiri dari berbagai jenis bahan baku (multi item). Kebutuhan bahan baku yang digunakan memiliki sifat yang tidak pasti pada setiap periodenya. PT. SEA bekerja sama dengan beberapa supplier untuk memasok bahan baku yang digunakan dalam pembuatan AlQuran, salah satunya adalah PT. CMI yang memasok jenis bahan baku paling banyak dari supplier yang lain. Sistem persediaaan yang dilakukan oleh perusahaan masih menggunakan intuisi, sehingga perusahaan melakukan pemesanan secara terpisah pada setiap jenis bahan baku apabila persediaan bahan baku di gudang mengalami kekurangan. 
Perusahaan tidak menggunakan suatu metode yang dilakukan untuk melakukan pengendalian pada persediaan bahan baku. Pengendalian bahan baku tanpa menggunakan metode yang tepat akan mengakibatkan masalah yaitu seperti tingginya ongkos yang dikeluarkan akibat adanya penyimpan bahan baku berlebih dan tingginya ongkos pesan karena frekuensi pemesanan yang sering.

I. Perusahaan melakukan pemesanan secara terpisah pada setiap jenis bahan baku, walaupun bahan baku yang dipesan tersebut berasal dari satu supplier yang sama. Hal tersebut mengakibatkan tingginya ongkos yang harus dikeluarkan oleh perusahaan. Pada umumnya hal tersebut dapat diminimasi dengan pemesanan item bahan baku yang dilakukan secara gabungan dari satu pemasok yang sama, karena Metode Joint replenishment digunakan karena sesuai dengan karakteristik perusahaannya yaitu hanya memiliki satu pemasok (Rahmadika, dkk, 2016). Metode yang digunakan untuk menyelesaikan masalah tersebut adalah metode joint replenishment. Dengan menggunakan metode ini, pemesanan bahan baku akan dilakukan setiap interval waktu tertentu dan jumlah pemesanan yang sama, dengan selisih inventori maksimum dengan inventori yang ada pada saat pemesanan akan dilakukan.

Dengan dilakukannya pemesanan secara bersama ini membuat syarat minimum order dapat terpenuhi.Kebijakan inventori terkait dengan berapa jumlah barang yang akan dipesan, kapan saat pemesanan dilakukan, serta berapa jumlah inventori pengamannya (Wangke, 2014)

Sehingga diharapkan pengendalian persediaan bahan baku dapat berjalan dengan lancar dan ongkos total persediaan menjadi minimum, karena menggabungkan

\section{KAJIAN PUSTAKA}

\section{Pengertian Persediaan}

Menurut Bahagia (2006) persediaan adalah suatu sumber daya menganggur (idle resources) yang keberadaannya menunggu proses lebih lanjut. Yang dimaksud dengan proses lebih lanjut di sini dapat berupa kegiatan pproduksi seperti dijumpai pada sistem manufaktur, kegiatan pemasaran seperti yang dijumpai pada sistem distribusi, ataupun kegiatan konsumsi seperti dijumpai pada sistem rumah tangga, perkantoran, dan sebagainya.

\section{Fungsi Persediaan}

Menurut Bahagia (2006), fungsi dari persediaan terbagi menjadi tiga jenis motif, yaitu motif transaksi, motif berjaga-jaga, dan motif berspekulasi; 1) Motif Transaksi (Transcaction Motive); motif transaksi digunakan untuk menjamin pemenuhan permintaan barang, 2) Motif Berjaga-Jaga (Precautionary Motive), 3) Motif berjaga-jaga digunakan untuk meredam ketidakpastian. Motif ini timbul bila terjadi adanya ketidakpastian baik dari sisi pasokan (supplier) abarang ataupun dari sisi pemakai barang (user). 4) Motif Berspekulasi (Speculative Motive) Keberadaan persediaan pada motif berspekulasi timbul karena adanya keinginan untuk mendapatkan keuntungan yang berlipat ganda dari kenaikan harga barang di masa yang akan mendatang.

\section{Model Persediaan}

Menurut Bahagia (2006) secara statistik, fenomena yang dapat diprediksi parameter populasinya baik ekspektasi, variansi, maupun pola distribusi kemungkinannnya. Untuk menentukan kebijakan dalam permasalahan inventori, dapat dipecahkan dengan menggunakan model Q dan model P.

\section{Sistem Persediaan Model- $Q$}

Sistem persediaan Model- $Q$ berkaitan dengan penentuan besarnya ukuran lot pemesanan yang ekonomis (qo) dan penentuan indikator saat pemesanan ulang dilakukan atau yang disebut dengan reorder point $(r)$. Karakteristik pada kebijakan inventori Model- $Q$ ditandai oleh dua hal yang mendasar yaitu sebagai berikut; 1) Besarnya ukuran lot pemesanan (qo) selalu tetap untuk setiap kali pemesanan dilakukan. 2) Pemesanan dilakukan apabila jumlah inventori yang dimiliki telah mencapai suatu tingkat tertentu $(r)$ yang disebut sebagai titik pemesanan ulang (reorder point).

\section{Sistem Persediaan Model- $P$}

Sistem persediaan Model- $P$ disebut juga sebagai periodic review. Sistem persediaan dengan menggunkan Model-P ini dilakukan dengan memeriksa persediaan dalam interval waktu tertentu (T). Dimana interval waktu tersebut bernilai tetap antara satu siklus pemesanan dengan siklus pesan yang lain. Penentuan jumlah pesanan (qo) dilakukan setiap periode $T$ dan besarannya akan berbeda-beda antara satu pemesanan dengan pemesanan yang lain. Karakteristik kebijakan inventori Model- $P$ ditandai oleh dua elemen dasar sebagai berikut;

a. Pemesanan dilakukan menurut suatu selang interval waktu yang tetap $(T)$.

b. Ukuran lot pemesanan (qo) besarnya merupakan selisih antara inventori maksimum yang diinginkan $(R)$ dengan inventori yang ada pada saat pemesanan dilakukan $(r)$. 
Pengendalian dengan menggunakan Model- $P$ dilakukan menurut interval waktu $(T)$ dan jumlah yang dipesan berubah-ubah sesuai dengan selisih inventori maksimum dengan inventori yang ada di gudang.

Model-P berfungsi dengan cara yang berbeda dibandingkan dengan Model-Q karena hal-hal berikut. 1) Model-P tidak memiliki titik pemesanan kembali, tetapi lebih menekankan pada target persediaan. 2) Model-P, tidak memiliki nilai EOQ karena pemesanan akan bervariasi tergantung permintaan yang sesuai dengan target persediaan. 3) Dalam Model-P, interval pemesanannya tetap sedangkan kuantitas pesanannya berubah-ubah.

\section{Model Persediaan Stokastik Untuk Kasus Joint Replenishment}

Model persediaan untuk kasus joint replenishment dikembangkan oleh Eynan \& Kropp (1998). Pendekatan yang digunakan ialah pendekatan Model- $P$ atau model periodic review. Pada persediaan dengan sistem persediaan Model- $P$, tingkat persediaan dimonitor setiap interval tertentu dan pemesanan dilakukan dengan jumlah untuk mencapai titik persediaan yang maksimum. Sistem persediaan Model- $P$ dapat diterapkan untuk kasus single item (jumlah item satu) dan multi-item (jumlah item banyak).

Model- $P$ terbagi kedalam dua bagian yaitu Model- $P$ dengan permintaan yang bersifat deterministik dan Model- $P$ dengan permintaan stokastik. Model- $P$ dengan permintaan deterministik digunakan apabila data bersifat tetap untuk setiap periode, sedangkan Model- $P$ stokastik digunakan apabila data jumlah permintaan bersifat tidak tetap untuk setiap periodenya. membuktikan dihasilkan berupa interval review, reorder point, jumlah maksimum inventori, safety stock, serta penghematan terhadap total ongkos persediaan (Rosyada, dkk., 2017). Hanya saja dalam penelitiannya tidak mempertimbangkan frekuensi waktu pemesanan.

\section{Kasus Multi Item}

Pada kasus multi-item penerapan model periodic review memerlukan kordinasi pemesanan. Pada kasus ini penentuan interval relatif sulit dibandingkan dengan kasus single item dan penentuan interval pemesanan hanya sebatas mendekati optimal (near optimal). Dengan model multi item berdasakan penelitian Noh, dkk, (2019), dapat menghasilkan pengisian bersama multi item, dan algoritma untuk menemukan siklus dasar meminimalkan biaya, pengganda interval pesanan, dan faktor keselamatan diusulkan. Hasil percobaan komputasinya, menunjukkan bahwa algoritma dapat menemukan solusi yang hampir optimal untuk masalah tersebut.

\section{Asumsi Model}

Model yang digunakan mengasumsikan bahwa pola permintaan berdistribusi normal.

2. Notasi Yang Digunakan

Berikut ini adalah notasi-notasi yang digunakan oleh kasus single item.

$a_{i}=$ Ongkos pesan minor item $i$.

$h_{i}=$ Ongkos simpan item $i$ per unit waktu.

$D_{i}=$ Rata-rata permintaan item $i$ selama unit waktu.

$z_{i}=$ Koefisien normal/faktor pengali $\sigma$ (ditentukan berdasarkan service level).

$\sigma_{i}=$ Standar deviasi dari permintaan item $i$.

$T_{0}=$ Interval antar pemesanan optimal/cycle time.

$L_{i}=$ Lead time item ke- $i$.

$A=$ Ongkos pesan mayor.

3. Formulasi Model

a. Ongkos Pesan

Ongkos pesan terbagi menjadi ongkos pesan mayor dan ongkos pesan minor dengan menggunakan persamaan sebagai berikut:
a. Ongkos mayor total $=\frac{A}{T}$
b. Ongkos pesan minor item $i=\frac{a_{i}}{T_{i}}(2)$
c. Ongkos pemesanan total $=\frac{A}{T}+$ Ongkos Simpan (3)

Besarnya ongkos simpan yaitu besarnya unit yang disimpan meliputi rata-rata jumlah permintaan selama interval pemesanan dan lead time serta safety stock untuk mengantisipasi fluaktuasi permintaan selama interval pemesanan dan lead time. Persamaan yang digunakan adalah:

Ongkos total simpangan gabungan = $\sum_{i=1}^{n}\left[\frac{D\left(T_{i}+L_{i}\right) h_{i}}{2}+z_{i} \sigma_{i} h_{i} \sqrt{k_{i} T+L_{i}}\right]$

b. Ongkos Total Persediaan Gabungan (OT)

Ongkos total persediaan gabungan adalah ongkos total persediaan dari sejumlah $n$ item. Besarnya ongkos total persediaan gabungan adalah:

$$
\begin{aligned}
& O T=\frac{A}{T}+\frac{\sum_{i=1}^{n} \frac{a_{i}}{k_{i}}}{T}+\sum_{i=1}^{n}\left[\frac{D\left(T_{i}+L_{i}\right) h_{i}}{2}+\right. \\
& \left.z_{i} \sigma_{i} h_{i} \sqrt{k_{i} T+L_{i}}\right]
\end{aligned}
$$




\section{Penentuan Interval Pemesanan Dasar}

Pemesanan gabungan (joint replenishment) dilakukan dengan menggunakan model periodic review. Model ini dilakukan dengan melakukan pemesanan setiap interval waktu tertentu. Interval waktu pemesanan tersebut bernilai tetap. Model persediaan periodic review dikembangkan oleh Eynan dan Kropp (1998). Variabel keputusan yang akan ditentukan adalah penentuan interval pemesanan dasar $(T)$, penentuan interval pemesanan setiap jenis bahan baku $\left(T_{i}^{*}\right)$, penentuan inventory level $\left(I L_{i}\right)$ dan perhitungan ongkos total persediaan gabungan $(O T)$, berikut merupakan langkah dalam penentuan interval pemesanan dapat dilihat dibawah ini.

\section{Langkah 1:}

Menentukan nilai $T_{0 i}$ dengan menggunakan persamaan $\sqrt{\frac{2 a_{i}}{h_{1} D_{1}}} \quad, \quad$ selanjutnya menentukan nilai $T_{i}^{*}$ dengan menggunakan

$$
\text { persamaan } \sqrt{\frac{2 a_{i}}{h_{1}\left(D_{1}+\frac{z_{i} \sigma_{i}}{\sqrt{k_{i} T_{0}+L_{i}}}\right)}}
$$

\section{Langkah 2:}

Identifikasi nilai $T_{i}^{*}$ item yang memiliki $T_{i}^{*}$ paling kecil dinotasikan sebagai item 1 , dengan nilai $k_{l}=1$. Dan item yang lainnya dinotasikan sebagai item $2,3,4 \ldots . \mathrm{n}$

\section{Langkah 3:}

Tentukan nilai $T$ dengan menggunakan persamaan $\sqrt{\frac{2\left(A+a_{i}\right)}{h_{i}\left(D_{i}+\frac{z_{i} \sigma_{i}}{\sqrt{T_{0}+L_{i}}}\right)}}$ dengan
nilai $T_{0}$ menggunakan persamaan
$\sqrt{\frac{2\left(A+a_{i}\right)}{h_{1} D_{1}}}$

\section{Langkah 4:}

Cari nilai $k_{i}$, jika $k_{i}=q$, sehingga nilai $q$ harus memenuhi persamaan $\sqrt{(k-1) k} \leq \frac{T_{i}^{*}}{T} \leq \sqrt{k(k+1)}$

(8)

\section{Langkah 5:}

Tentukan nilai $T$ dengan menggunakan persamaan $\sqrt{\frac{2\left(A+\sum_{i=1}^{n} \frac{a_{i}}{k_{i}}\right)}{\sum_{i=1}^{n} h_{i} k_{i}\left(D_{i}+\frac{z_{i} \sigma_{i}}{\sqrt{k_{i} T_{0}+L_{i}}}\right)}}$

dengan nilai $T_{0}$ menggunakan persamaan
$\sqrt{\frac{2\left(A+\sum_{i=1}^{n} \frac{a_{i}}{k_{i}}\right)}{\sum_{i=1}^{n} h_{i} k_{i} D_{i}}}$

\section{Langkah 6:}

Hitung ongkos total gabungan (OT) dengan menggunakan persamaan

$$
\begin{aligned}
\text { OT }=\frac{A}{T}+\frac{a_{i}}{T_{i}}+\frac{\sum_{i=2}^{n} \frac{a_{i}}{k_{i}}}{T}+\frac{D\left(T_{i}+L_{i}\right) h_{i}}{2}+\mathrm{z}_{\mathrm{i}} \sigma_{i} \\
\\
h_{i} \sqrt{T_{i}+L_{i}}+\sum_{i=2}^{n}\left[\frac{D\left(T_{i}+L_{i}\right) h_{i}}{2}+\right. \\
\left.\quad \text { zi } \sigma_{i} h_{i} \sqrt{k_{i} T+L_{i}}\right](10)
\end{aligned}
$$

Ulangi Langkah 4 dan Langkah 5 sehingga ongkos total persediaan gabungan yang didapatkan pada iterasi tersebut dan iterasi sebelumnya bernilai sama.

\section{METODOLOGI PENELITIAN}

Langkah yang dilakukan dalam melakukakan penelitian untuk mendapatkan pemecahan masalah dapat dilihat pada gambar 3 .

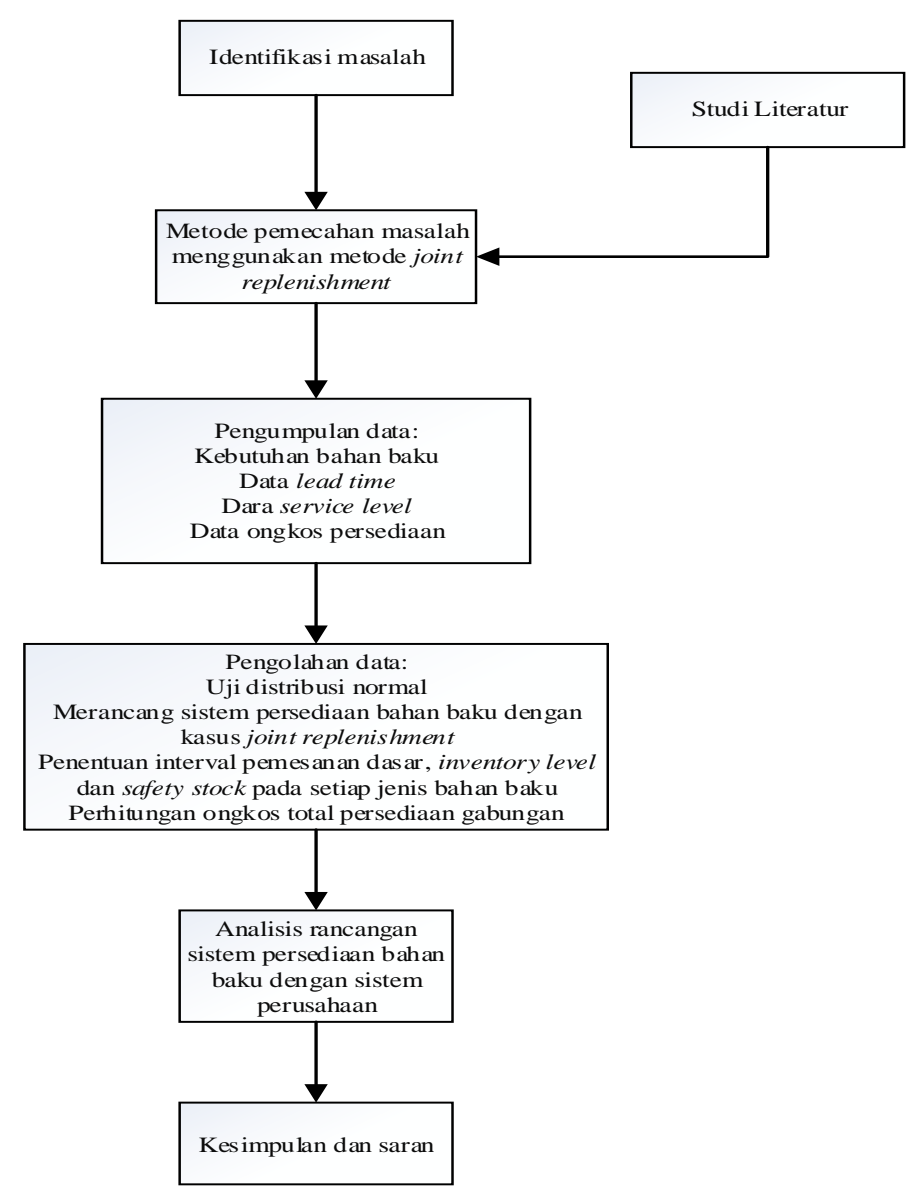

Gambar 3. Langkah-langkah Pemecahan Masalah

\section{HASIL DAN PEMBAHASAN}

\section{Pengumpulan Data}

Pengumpulan data berisikan data-data yang dibutuhkan dalam melakukan penelitian. Data-data yang dibutuhkan yaitu data kebutuhan bahan baku, 
harga beli bahan baku, lead time, ongkos-ongkos pesan yaitu ongkos pesan mayor dan ongkos pesan minor. Data kebutuhan untuk setiap jenis bahan baku pada bulan Januari hingga Desember tahun 2016 dapat dilihat pada Tabel 1.
Tabel 1. Data Kebutuhan Bahan Baku

Tabel 1. Data Kebutuhan Bahan Baku

\begin{tabular}{|c|c|c|c|c|c|c|}
\hline \multirow[t]{2}{*}{$\begin{array}{l}\text { Bahan } \\
\text { Baku }\end{array}$} & \multirow[t]{2}{*}{$\begin{array}{l}\text { QPP } \\
\text { (rim) }\end{array}$} & \multirow{2}{*}{$\begin{array}{l}\text { Art } \\
\text { Paper } \\
150 \mathrm{gr} \\
\text { (rim) }\end{array}$} & \multicolumn{2}{|c|}{$\begin{array}{l}\text { Art Carton } \\
210 \text { gr (rim) }\end{array}$} & \multicolumn{2}{|c|}{$\begin{array}{l}\text { Art Carton } \\
260 \mathrm{gr} \text { (rim) }\end{array}$} \\
\hline & & & $\begin{array}{l}65 \times 100 \\
\mathrm{~cm}\end{array}$ & $\begin{array}{l}79 \times 109 \\
\mathrm{~cm}\end{array}$ & $\begin{array}{l}65 \times 100 \\
\mathrm{~cm}\end{array}$ & $\begin{array}{l}79 \times 109 \\
\mathrm{~cm}\end{array}$ \\
\hline Januari & 171 & 15 & 4 & 8 & 3 & 7 \\
\hline Februari & 163 & 12 & 2 & 8 & 3 & 6 \\
\hline Maret & 176 & 16 & 4 & 5 & 3 & 9 \\
\hline April & 142 & 9 & 2 & 5 & 2 & 5 \\
\hline Mei & 184 & 17 & 3 & 6 & 4 & 7 \\
\hline Juni & 204 & 23 & 5 & 11 & 6 & 12 \\
\hline Juli & 155 & 16 & 3 & 9 & 2 & 7 \\
\hline Agustus & 152 & 14 & 4 & 10 & 5 & 5 \\
\hline September & 165 & 12 & 5 & 8 & 4 & 7 \\
\hline Oktober & 178 & 16 & 4 & 8 & 4 & 8 \\
\hline November & 139 & 8 & 4 & 7 & 3 & 10 \\
\hline Desember & 166 & 13 & 5 & 6 & 4 & 11 \\
\hline
\end{tabular}

Data harga beli bahan baku, lead time, ongkosongkos pesan yaitu ongkos pesan mayor dan ongkos pesan minor dapat dilihat pada Tabel 2.

Tabel 2. Harga Bahan Baku, Lead Time dan Ongkos Pesan

\begin{tabular}{cccccc}
\hline $\begin{array}{c}\text { Bahan } \\
\text { baku }\end{array}$ & $\begin{array}{c}\text { Ukuran } \\
(\mathbf{c m})\end{array}$ & $\begin{array}{c}\text { Harga beli } \\
(\text { Rp/rim) }\end{array}$ & $\begin{array}{c}\text { Lead } \\
\text { time } \\
\text { (hari) }\end{array}$ & $\begin{array}{c}\text { Ongkos } \\
\text { Pesan } \\
\text { Mayor } \\
(\mathbf{R p})\end{array}$ & $\begin{array}{c}\text { Ongkos } \\
\text { Pesan } \\
\text { Minor }(\mathbf{R p})\end{array}$ \\
\hline QPP & $70 \times 100$ & 248.000 & 7 & 850.000 & 1.100 .400 \\
Art Paper & $79 \times 109$ & 722.000 & 7 & 850.000 & 400 \\
$\begin{array}{c}\text { Art } \\
\text { Carton }\end{array}$ & $65 \times 100$ & 750.000 & 7 & 850.000 & 400 \\
$\mathbf{2 1 0}$ gr & $79 \times 109$ & 994.000 & 7 & 850.000 & 400 \\
$\begin{array}{c}\text { Art } \\
\text { Carton }\end{array}$ & $65 \times 100$ & 929.500 & 7 & 850.000 & 400 \\
$\mathbf{2 6 0}$ gr & $79 \times 109$ & 1.231 .000 & 7 & 850.000 & 400 \\
\hline
\end{tabular}

\section{Pengolahan Data}

Pengolahan data dilakukan untuk menghasilkan variabel keputusan dari hasil penelitian. Variabel keputusan tersebut meliputi interval penentuan dasar, interval pemesanan tiap jenis bahan baku, inventory level, dan ongkos total persediaan gabungan.

\section{Uji Distribusi Data Kebutuhan Bahan Baku Menggunakan Kolmogorov - Smirnov}

Uji distribusi dengan menggunakan kolmogorov smirnov dilakukan untuk mengetahui apakah data berdistribusi normal atau tidak. Langkah-langkah yang dilakukan dalam melakukan uji distribusi pada bahan baku QPP dapat dilihat dibawah ini.

1. Penentuan Hipotesa:

$\mathrm{H}_{0}$ : data berdistribusi normal

$\mathrm{H}_{1}$ : data tidak berdistribusi normal

2. Penentuan Taraf Keberartian $\alpha=0,02$

3. Daerah Kritis

Nilai $D_{\text {tabel }}$ dengan jumlah $n=12$ dan nilai $\alpha=0,02$ adalah 0,419

4. Mengurutkan Data Kebutuhan Bahan Baku.

Data kebutuhan bahan baku diurutkan berdasarkan jumlah yang paling kecil

5. Statistik Hitung

Perhitungan terhadap point 5 dilakukan untuk menentukan nilai $D_{\max }$ untuk setiap kebutuhan jenis bahan baku.

6. Penentuan nilai rata - rata $(\mu)$ dan standar deviasi $(\sigma)$

$\mu=\frac{\sum X i}{n}$

permintaan ke-i

Dimana, $X i: \quad$ data

$$
=\frac{1996}{12}=167
$$

$n$ : jumlah data

$\sigma=\sqrt{\frac{\sum(X i-\mu)^{2}}{n-1}}=18,26$

$$
\begin{gathered}
\text { 7. } F s(x)=\frac{f \text { kumulatif }}{\sum f i} \\
=\frac{1}{12}=0,08 \\
Z i=\frac{x i-\bar{x}}{\sigma} \quad(14) \\
=\frac{139-\overline{167}}{18,26}=-1,53
\end{gathered}
$$

8. $\quad F t(x)=$ penentuan hasil peluang dari tabel distribusi normal

9. $D=|F s(x)-F t(x)|$

$$
=|0,08-0,063|
$$$$
=0,020
$$

10. $D_{\max }=$ nilai terbesar dari $D$

Sehingga nilai $D_{\max }=0,108$

11. Kesimpulan

$D_{\max }<D_{\text {tabel }}(0,108<0,419)$ maka terima Ho, cukup alasan untuk menerima bahwa data berdistribusi normal.

Berdasarkan hasil pengujian kolmogorov-smirnov tersebut, seluruh bahan baku termasuk dalam data yang berdistribusi normal.

\section{Perancangan Sistem Persediaan}

Perancangan terhadap sistem persediaan bahan baku dilakukan dengan menghitung interval 
pemesanan dasar $(T)$, interval pemesanan setiap bahan baku $\left(T_{i}\right)$, inventory level $\left(I L_{i}\right)$ dan ongkos total gabungan $(O T)$.

\section{Penentuan Nilai Interval Pemesanan Dasar / Basic Cycle $(T)$}

Penentuan nilai interval pemesanan dasar memerlukan beberapa data seperti ongkos pesan, ongkos simpan, rata-rata kebutuhan bahan baku, standar deviasi, service level dan data lead time. Rekapitulasi input yang dibutuhkan dapat dilihat pada Tabel 4.

6.

Langkah 3: Menentukan nilai $T$ dengan menggunakan persamaan

$T=\sqrt{\frac{2\left(A+a_{1}\right)}{h_{1}\left(D_{1}+\frac{z_{1} \sigma_{1}}{\sqrt{T_{0}+L_{1}}}\right)}}$ dengan nilai

$T_{o}=$

$T_{0}=\sqrt{\frac{2\left(A+a_{1}\right)}{h_{1} D_{1}}}=\sqrt{\frac{2(850000+400)}{5415 \times 15}}=4,576$ bulan

$T=\sqrt{\frac{2\left(A+a_{1}\right)}{h_{1}\left(D_{1}+\frac{z_{1} \sigma_{1}}{\sqrt{T_{0}+L_{1}}}\right)}}=\sqrt{\frac{2(850000+400)}{5415\left(15+\frac{2,054 \times 3,96}{\sqrt{4,576+0,292}}\right)}}$

Tabel 4. Rekapitulasi Input

\begin{tabular}{|c|c|c|c|c|c|c|c|}
\hline $\begin{array}{c}\text { Bahan } \\
\text { Baku }\end{array}$ & $\begin{array}{c}\text { Ukuran } \\
\text { (cm) }\end{array}$ & $\begin{array}{l}\text { Ongkos } \\
\text { pesan } \\
\left(a_{i}\right) \\
(\mathbf{R p})\end{array}$ & $\begin{array}{l}\text { Ongkos } \\
\text { simpan } \\
\left(h_{i}\right) \\
(\mathbf{R p})\end{array}$ & $\begin{array}{c}D_{i} \\
\text { (bulan) }\end{array}$ & $\begin{array}{c}\text { Koefisien } \\
\text { normal } \\
\left(Z_{i}\right)\end{array}$ & $\sigma_{i}$ & $\begin{array}{l}\text { Lead } \\
\operatorname{t+m} 4,100 \text { bulan } \\
\text { (hari) } \\
\text { Langkah 4: Menentukan nilai } k \text { pada item lainnya }\end{array}$ \\
\hline QPP & $\begin{array}{l}70 x \\
100\end{array}$ & 1.100 .400 & 1.860 & 167 & 2,054 & 18,26 & yajetr $k_{2}, k_{3}$ dan $k_{4}$. Penentuan nilai $k_{i}$ ditentukan \\
\hline $\begin{array}{c}\text { Art } \\
\text { Paper }\end{array}$ & $\begin{array}{l}79 \times \\
109\end{array}$ & 400 & 5.415 & 15 & 2,054 & 3,96 & $\begin{array}{l}\text { deg,egan trial and error sehingga nilai } k_{i} \text { yang } \\
\text { diperoleh dapat memenuhi persamaan: }\end{array}$ \\
\hline
\end{tabular}

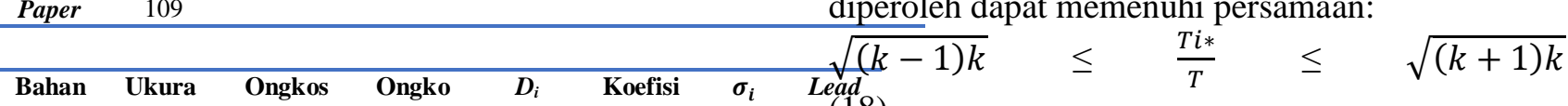

$\begin{array}{cccccccc}\text { Bahan } & \text { Ukura } & \text { Ongkos } & \text { Ongko } & D_{i} & \text { Koefisi } & \sigma_{i} & \text { Lead } \\ \text { Baku } & \mathrm{n}(\mathrm{cm}) & \text { pesan } & \mathrm{s} & \text { (bulan } & \text { en } & & \end{array}$

$\left(a_{i}\right) \quad$ simpa $\quad$ norma $\quad$ (hari

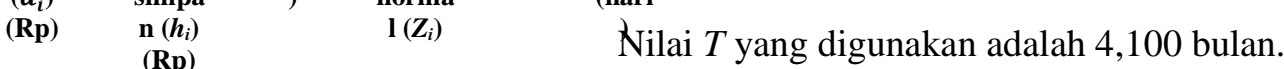

\begin{tabular}{|c|c|c|c|c|c|c|c|c|c|}
\hline & & & (Rp) & & & & & & \\
\hline Art & $65 x$ & 400 & 5.625 & 4 & 2,054 & 1,06 & 0,292 & & \\
\hline Carto & 100 & & & & & & Langkah 5: Menentukan & nilai & denga \\
\hline $\begin{array}{l}n 210 \\
\text { gr }\end{array}$ & $\begin{array}{c}79 x \\
109\end{array}$ & 400 & 7.455 & 8 & 2,054 & 1,88 & 0,292 menggunakan persamaan: & & \\
\hline
\end{tabular}

gr 109

$\begin{array}{cc}\text { Art } & 65 \\ \text { Carto } & 100\end{array}$

n 26079

gr $\quad 109$

\section{Iterasi 1}

Iterasi 1 merupakan tahap awal yang dilakukan dalam penentuan nilai $T$. Perhitungan iterasi ini dapat dilakukan hingga berbagai iterasi. Iterasi ini akan berhenti apabila ongkos yang dihasilkan sama dengan ongkos yang dihasilkan pada iterasi sebelumnya.

Langkah 1: Menentukan nilai $T_{i}{ }^{*}$ pada setiap jenis bahan baku dengan menggunakan persamaan:

$T_{i}^{*}=\sqrt{\frac{2\left(a_{i}\right)}{h_{i}\left(D_{i}+\frac{z_{i} \sigma_{i}}{\sqrt{T_{0}+L_{i}}}\right)}}$, dengan nilai $T_{0}=\sqrt{\frac{2\left(a_{i}\right)}{h_{i} D_{i}}}$

Langkah 2: Identifikasi nilai $T_{i} *$ terkecil. Bahan baku yang memiliki $T_{i} *$ paling kecil dinotasikan sebagai item 1 , dengan nilai $k_{i}=1$.

Berdasarkan langkah 1 yang dihasilkan, urutan nilai $T_{i} *$ mulai dari yang paling kecil adalah art carton 210gr, art carton 260gr, art paper dan QPP. Nilai $T_{i}{ }^{*}$ yang paling kecil berada pada jenis bahan baku art carton $210 \mathrm{gr}$ sehingga bahan baku art carton 210gr disebut sebagai item 1 dengan nilai $k_{1}=1$. Sedangkan lain memiliki urutan item 2, 3, 4, 5 dan dimana

$$
T_{0}=\sqrt{\frac{2\left(A+\sum_{i=1}^{n} \frac{a_{i}}{k_{i}}\right)}{\sum h_{i} k_{i} D_{i}}}
$$

$$
\begin{aligned}
T_{0} & =\sqrt{\frac{2\left(A+\sum_{i=1}^{n} \frac{a_{i}}{k_{i}}\right)}{\sum h_{i} k_{i} D_{i}}}=\sqrt{\frac{2(850000+1102400)}{575730}} \\
& =2,604 \text { bulan }
\end{aligned}
$$

$$
\begin{aligned}
T & =\sqrt{\frac{2\left(A+\sum_{i=1}^{n} \frac{a_{i}}{k_{i}}\right)}{\sum_{i=1}^{n} h_{i} k_{i}\left(D_{i}+\frac{Z_{i} \sigma_{i}}{\sqrt{k_{i} T_{0}+L_{i}}}\right)}}=\sqrt{\frac{2(850000+1102400)}{731145,09}} \\
& =2,311 \text { bulan }
\end{aligned}
$$

Langkah 6: Menentukan Total Biaya (OT) Penentukan total biaya persediaan memerlukan beberapa input, seperti nilai $a_{i}, k_{i}, Z_{i}, \sigma_{i}, L_{i}$ dan $h_{i}$. Penenuan total biaya (OT) dapat digunakan dengan menggunakan persamaan:

$$
\begin{aligned}
& O T=\frac{A}{T}+\frac{a_{i}}{T_{i}}+\frac{\sum_{i=2}^{n} \frac{a_{i}}{k_{i}}}{T}+\frac{D\left(T_{i}+L_{i}\right) h_{i}}{2}+\mathrm{Z}_{\mathrm{i}} \sigma_{i} \\
& h_{i} \sqrt{T_{i}+L_{i}}+\sum_{i=2}^{n}\left[\frac{D\left(T_{i}+L_{i}\right) h_{i}}{2}+\right.
\end{aligned}
$$




$$
\begin{aligned}
& \text { zi } \left.\sigma_{i} h_{i} \sqrt{k_{i} T+L_{i}}\right] \\
& O T=\frac{850.000}{2,311}+\frac{400}{2,311}+\frac{1.101 .600}{2,311}+ \\
& \frac{15(2,311+0,292) 5.415}{2}+2,054 \times 3,96 \times 5.415 \\
& \sqrt{2,311+0,292} \\
& \quad+547.396,75+205.587,94 \\
& =\text { Rp } 1.774 .350,76 / \text { bulan }
\end{aligned}
$$

\section{Iterasi 2}

Pada iterasi ke 2 ini dimulai dari langkah 4. Langkah 4 ini dilakukan untuk menentukan nilai $\mathrm{k}_{2}$ $\mathrm{k}_{3}$ dan $\mathrm{k}_{4}$. Penentuan nilai $\mathrm{k}_{\mathrm{i}}$ ini dilakukan dengan menggunakan trial and error sehingga nilai $\mathrm{k}_{\mathrm{i}}$ yang diperoleh dapat memenuhi persamaan (3) dengan menggunakan nilai $T$ sebesar 2,311 bulan.

Nilai $k_{i}$ perhitungan iterasi berhenti ketika nilai $k_{i}$ yang dihasilkan sama dari iterasi sebelumnya. Dari hasil perhitungan tersebut, maka diperoleh nilai $T$ yaitu sebesar 2,311 bulan.

\section{Penentuan Interval Pemesanan Pada Setiap Jenis Bahan Baku $\left(T_{i}\right)$}

Penentuan interval pemesanan untuk setiap jenis bahan baku $\left(T_{i}\right)$ didapatkan dengan mengkalikan nilai $k_{i}$ dengan nilai $T$. Rekapitulasi interval pemesanan pada setiap jenis bahan baku dapat dilihat pada Tabel 5 .

Tabel 5. Rekapitulasi Interval Pemesanan Pada Setiap Jenis Bahan Baku

\begin{tabular}{lllllll}
\hline No & Bahan & $\begin{array}{l}\text { Ukuran } \\
\text { Baku }\end{array}$ & $\boldsymbol{k}_{\boldsymbol{i}}$ & $\boldsymbol{T}$ & $\boldsymbol{T}_{\boldsymbol{i}}$ & \\
\cline { 5 - 7 } $\mathbf{( c m )}$ & QPP & $70 \times 100$ & 1 & 2,311 & 2,311 & 10 \\
$\mathbf{2}$ & Art Paper & $79 \times 109$ & 1 & 2,311 & 2,311 & 10 \\
$\mathbf{3}$ & Art Carton & $65 \times 100$ & 1 & 2,311 & 2,311 & 10 \\
$\mathbf{4}$ & 210 gr & $79 \times 109$ & 1 & 2,311 & 2,311 & 10 \\
$\mathbf{5}$ & Art Carton & $65 \times 100$ & 1 & 2,311 & 2,311 & 10 \\
$\mathbf{6}$ & 260 gr & $79 \times 109$ & 1 & 2,311 & 2,311 & 10 \\
\hline
\end{tabular}

Contoh perhitungan interval pemesanan $\left(T_{i}\right)$ pada bahan baku QPP:

$$
\begin{aligned}
T_{i}(\text { bulan }) & =k_{i} \times T \\
T_{i}(\text { minggu }) & =T_{i}(\text { bulan }) \times 4 \text { minggu } \\
& =1 \times 2,311 \\
& =2,311 \times 4 \\
& =2,311 \text { bulan } \\
& =9,244=10 \text { minggu }
\end{aligned}
$$

\section{Penentuan Inventory Level $\left(I L_{i}\right)$}

Inventory level digunakan untuk memenuhi permintaan selama interval waktu pemesanan dan lead time. Untuk menanggulangi fluktuasi permintaan maka diperlukan perhitungan terhadap safety stock. Perhitungan inventory level dan safety stock untuk setiap jenis bahan baku dapat dilihat pada Tabel 6.

\section{Tabel 6. Penentuan Inventory Level dan Safety}

\section{Stock}

\begin{tabular}{|ccccc}
\hline No & Bahan Baku & $\begin{array}{c}\text { Ukuran } \\
(\mathbf{c m})\end{array}$ & $\begin{array}{c}\text { Safety } \\
\text { Stock } \\
\text { (rim) }\end{array}$ & $\begin{array}{c}\text { Inventory } \\
\text { Level } \\
\text { (rim) }\end{array}$ \\
\hline $\mathbf{1}$ & QPP & $70 \times 100$ & 61,00 & 496,00 \\
\hline $\mathbf{2}$ & Art Paper & $79 \times 109$ & 14,00 & 53,00 \\
\hline $\mathbf{3}$ & Art Carton 210 & $65 \times 100$ & 4,00 & 14,00 \\
\hline $\mathbf{4}$ & gr & $79 \times 109$ & 7,00 & 28,00 \\
\hline $\mathbf{5}$ & Art Carton 260 & $65 \times 100$ & 4,00 & 15,00 \\
\hline $\mathbf{6}$ & gr & $79 \times 109$ & 8,00 & 29,00 \\
\hline
\end{tabular}

Contoh perhitungan terhadap safety stock dan inventory level pada bahan baku QPP:

a. Safety stock $=z_{i} \sigma_{i} \sqrt{T_{i}+L_{i}}$

$$
\begin{gathered}
=2,054 \times 18,26 \sqrt{2,311+0,292} \\
=61 \mathrm{rim}
\end{gathered}
$$

b. Inventory level $=D_{i}\left(k_{i} T+L_{i}\right)+$

$$
z_{i} \sigma_{i} \sqrt{T_{i}+L_{i}}
$$

)

$$
\begin{aligned}
= & 167(1 \times 2,311+0,292)+2,054 \\
\mathrm{x} & \\
& 18,26 \sqrt{2,311+0,292} \\
= & 496 \mathrm{rim}
\end{aligned}
$$

\subsubsection{Penentuan Ongkos Total Persediaan Gabungan $(O T)$}

Ongkos total persediaan gabungan didapat dari perhitungan pada iterasi 1 . Dengan nilai $T$ sebesar 2,472 bulan.

$$
\begin{aligned}
& O T=\frac{A}{T}+\frac{a_{i}}{T_{i}}+\frac{\sum_{i=2 \frac{a_{i}}{k_{i}}}^{T}+\frac{D\left(T_{i}+L_{i}\right) h_{i}}{2}+\mathrm{z}_{\mathrm{i}} \sigma_{i}}{2}+\quad \sum_{i=2}^{n}\left[\frac{D\left(T_{i}+L_{i}\right) h_{i}}{2}+\right. \\
& h_{i} \sqrt{T_{i}+L_{i}}+ \\
& \left.\operatorname{zi~} \sigma_{i} h_{i} \sqrt{k_{i} T+L_{i}}\right](23) \\
& O T=\frac{850.000}{2,311}+\frac{400}{2,311}+\frac{1.101 .600}{2,311}+ \\
& \frac{15(2,311+0,292) 5.415}{2}+2,054 \times 3,96 \times 5.415 \\
& \sqrt{2,311+0,292} \times \\
& \quad+547.396,75+205.587,94 \\
& =\text { Rp 1.774.350,76/ bulan }
\end{aligned}
$$

ANALISIS RANCANGAN SISTEM 


\section{PERSEDIAAN BAHAN BAKU}

Total Ongkos Persediaan Hasil Rancangan Berdasarkan Data Masa Lalu

Perhitungan total ongkos persediaan ini dilakukan berdasarkan hasil rancangan dan metode perusahaan menggunakan data masa lalu. Setelah dilakukan perhitungan kedua ongkos total tersebut, dilakukan perbandingan total ongkos akhir yang dihasilkan paling minimum. Total ongkos persediaan hasil rancangan berdasarkan data masa lalu dapat dilihat pada Tabel 7.

Tabel 7. Total Ongkos Persediaan Berdasarkan Hasil Rancangan

\begin{tabular}{llll}
\hline No & Jenis Ongkos & \multicolumn{2}{c}{ Ongkos (Rp/tahun) } \\
\hline 1 & Ongkos Simpan & & $\mathrm{Rp} 9.705 .063,75$ \\
2 & $\begin{array}{l}\text { Ongkos Pesan } \\
\text { Minor) }\end{array}$ & (Mayor + & $\mathrm{Rp} 9.762 .000,00$ \\
3 & Ongkos Pembelian & & $\mathrm{Rp} \mathrm{961.687.500,00}$ \\
Total & & $\mathrm{Rp} \mathrm{981.154.563,75}$ \\
\hline
\end{tabular}

\section{Total Ongkos Persediaan Yang Dijalankan Oleh} Perusahaan

Pemesanan bahan baku secara terpisah untuk masing-masing bahan baku, tanpa mempertimbangkan jenis bahan baku lain yang berasal dari supplier yang sama. Frekuensi pemesanan perusahaan selama satu tahun dilakukan yaitu sebanyak 13 kali. Total ongkos persediaan yang dijalankan oleh perusahaan dapat dilihat pada Tabel 8.

Tabel 8. Total Ongkos Persediaan Berdasarkan

\section{Perusahaan}

\begin{tabular}{lll}
\hline No & Jenis Ongkos & Ongkos (Rp/tahun) \\
\hline 1 & Ongkos Simpan & $2.778 .067,50$ \\
2 & $\begin{array}{l}\text { Ongkos Pesan (Mayor }+ \\
\text { Minor) }\end{array}$ & $25.375 .200,00$ \\
& Ongkos Pembelian & $961.687 .500,00$ \\
\hline Total & & $989.840 .767,50$ \\
\hline
\end{tabular}

\section{Analisis Perbandingan Sistem Persediaan Rancangan Dengan Metode Yang Digunakan Oleh Perusahaan}

Rancangan pada sistem persediaan bahan baku tersebut dikategorikan termasuk dalam Model- $P$. Pemesanan terhadap bahan baku yang telah dilakukan perusahaan dilakukan ketika persediaan mendekati titik pemesanan kembali reorder point). Sehingga sistem persediaan yang digunakan oleh perusahaan menggunakan Model- $Q$. Pemesanan yang dilakukan secara gabungan (joint replenishment) dapat mempengaruhi frekuensi pemesanan dalam satu tahun. Jumlah pemesanan yang telah dilakukan perusahaan dalam 1 tahun yaitu sebanyak 13 kali. Sedangkan hasil rancangan terhadap data masa lalu menghasilkan 5 kali pemesanan per tahunnya. Berdasarkan hasil rancangan total ongkos persediaan yang dihasilkan yaitu sebesar Rp 982.254.563,75 per tahun, sedangkan total ongkos persediaan yang dilakukan oleh perusahaan yaitu sebesar Rp 989.840.767,50per tahun. Sehingga dapat dilihat bahwa total ongkos persediaan berdasarkan hasil rancangan menghasilkan nilai yang lebih minimum jika dibandingkan dengan total ongkos persediaan yang dilakukan oleh perusahaan.

\section{KESIMPULAN}

Kesimpulan yang diperoleh dari hasil penelitian adalah:

a. Frekuensi pemesanan yang telah dilakukan oleh perusahaan sebanyak 13 kali pemesanan per tahun. Sedangkan, berdasarkan hasil rancangan dengnan menggunakan data masa lalu dan data bilangan random, frekuensi pemesanan dilakukan 5 kali per tahun. Sehingga menghasilkan penghematan frekuensi waktu pemesanan sebesar $61,58 \%$.

b. Total ongkos persediaan dengan metode perusahaan berdasarkan data masa lalu yaitu sebesar Rp 989.840.767,50 per tahun per tahun. Total ongkos persediaan dengan menggunakan hasil rancangan bernilai Rp 982.254.563,75 per tahun. menghemat sekitar Rp. 7.586.20375 pertahun atau turun sekitar $0,7 \%$.

\section{REFERENSI}

Bahagia, S. N.(2006). Sistem Inventori, Penerbit ITB, Bandung.

Eynan, A., \& Kropp, D. H., (1998). Periodic Reviewed Joint Replenishment In Stochastic Demand Environment, IIE Transaction, Washington.

Heizer, (2012). Operation Management. Salemba Empat. Jakarta.

Noh, J.S., Kim, J.S. \& Sarkar, B. (2019). Stochastic joint replenishment problem with quantity discounts and minimum order constraints. Operational Research International Journal, 19, 151-178. Springer.

Rosyada, P., Iqbal, M., dan Astuti, M.D., (2017). Perencanaan Kebijakan Persediaan Kategori Floor Tile Dengan Model P Dan Joint Replenishment Untuk Meminimasi Total Biaya Persediaan Pada Central Warehouse PT.Xyz Karawang, Jurnal Rekayasa Sistem \& Industri, 4(2), 124 -129.

T. I. Rahmadika, D. D. Damayanti and B. Santosa. (2016) "Penentuan Kebijakan Persediaan Darah di Bank Darah Rumah Sakit XYZ Menggunakan Metode Joint Replenishment untuk Meningkatkan Service Level," in e-Proceeding Telkom University, Bandung. 
Tersine, R. J., (1994). Principle of Inventory and Materials Management, 3rd Edition, Elsevier S Wanke, P. (2014). Production and Inventory Management Journal, Production and Inventory Management Journal, 49 (1). 